Portland State University

PDXScholar

\title{
An Examination of Gentrification and Related Displacement of Black Residents in Portland's Boise Neighborhood, 1990-2010
}

Jordan Jordan

Portland State University

Follow this and additional works at: https://pdxscholar.library.pdx.edu/honorstheses

Part of the Urban Studies Commons

Let us know how access to this document benefits you.

\section{Recommended Citation}

Jordan, Jordan, "An Examination of Gentrification and Related Displacement of Black Residents in Portland's Boise Neighborhood, 1990-2010" (2013). University Honors Theses. Paper 16.

https://doi.org/10.15760/honors.23

This Thesis is brought to you for free and open access. It has been accepted for inclusion in University Honors Theses by an authorized administrator of PDXScholar. Please contact us if we can make this document more accessible: pdxscholar@pdx.edu. 
An Examination of Gentrification and Displacement of Black Residents in Portland's Boise Neighborhood, 1990-2010

by

\author{
Jordan Jordan
}

\begin{abstract}
An undergraduate honors thesis submitted in partial fulfillment of the Requirements for the degree of Bachelor of Science

In

University Honors

and

Community Development
\end{abstract}

Thesis Adviser

Dr. Richard White

Portland State University

2013

Jordan | 1 
Introduction

The revitalization of the long-depressed N Mississippi Avenue business district in Portland's Boise neighborhood, which has undergone a complete rebirth - from a haven for gang activity and drug use to a hip and trendy destination neighborhood, complete with busy restaurants, quirky boutiques, and a vibrant night life- is rightly considered a success story. But by practically any measure, gentrification was afoot here, and the results were not entirely positive for the African American community that constituted a substantial majority of the neighborhood prior to its revitalization. In 1990, a few years before the revitalization began in earnest, the Boise neighborhood had the highest concentration of African American residents in the city. Multnomah County Census Tract 34.02, which encapsulates nearly the entirety of the neighborhood, was 70.2\% Black; by 2010, that figure had dropped to $26.9 \% .{ }^{1}$ Over the same period, the proportion of White residents in the Census Tract climbed from $23.3 \%$ to $59.7 \% .^{2}$ This stark demographic shift coincides with an equally pronounced economic transition, indicated by dramatic gains in average gross rents, median home prices, median household income, and educational attainment figures.

The diminishment of its once-defining Black population is not a unique phenomenon among Portland's inner north and northeast neighborhoods, which have long formed the heart of the city's African American community. As Nikole Hannah-Jones points out in her

\footnotetext{
${ }^{1}$ It should be noted that these figures represent residents who self-identified on the Census as "Black or African American alone" and not "Black or African American alone or in combination." This is due to the fact that the latter designation did not exist prior to the 2000 Census; in the interest of continuity and producing a more accurate account of the demographic transition of Boise, the former will be used for comparisons of data from the 1990 Census.

${ }^{2}$ As above, "White alone" was chosen for reasons of continuity with the 1990 Census
} 
April 30, 2011 story in The Oregonian, inner north and northeast Portland remain home to the highest concentration of African Americans in the state, but between 2000, when people of color outnumbered whites in 10 of the area's census tracts, and 2010, all of those tracts had flipped to majority White. As Jones reports, Portland, "already the Whitest major city in the country, has become Whiter at its core even as surrounding areas have grown more diverse." She notes that of 354 census tracts in Multnomah, Washington and Clackamas counties, 40 became whiter from 2000 to 2010, according to The Oregonian's analysis of the 2010 Census. Of those, two lie in rural Clackamas County. The 38 others are in Portland (Jones). While these figures are striking, and certainly indicative of a larger trend in Portland, the particular case of Boise deserves special consideration because of its standing as a key neighborhood for Portland's Black community.

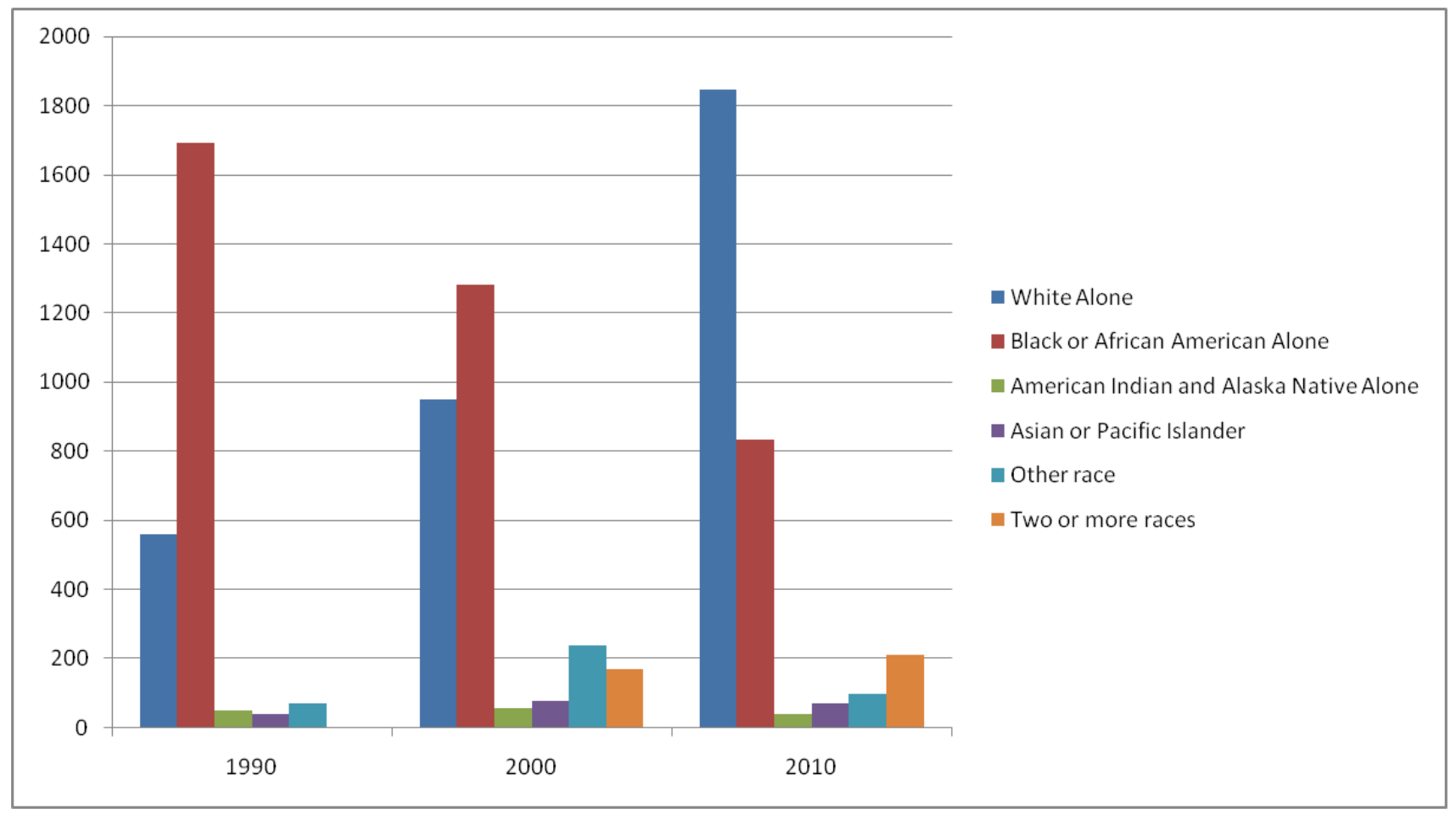

Figure 1: Racial composition of Multnomah County Census Tract 34.02, 1990-2010 


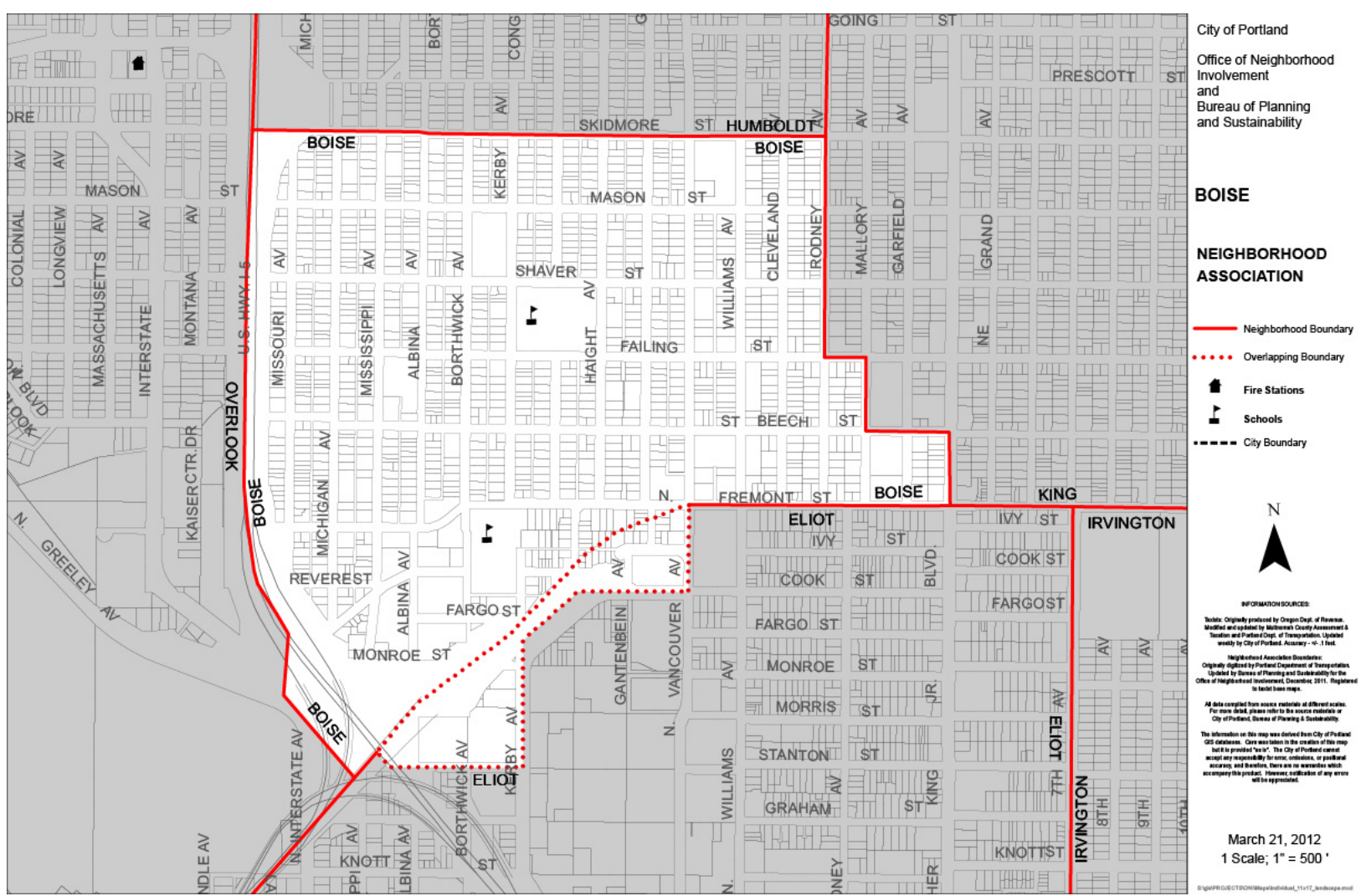

Map of the Boise neighborhood (Boise Neighborhood Association)

Background

This is not the first time Boise has witnessed a major shift in demographics. Before

African Americans were funneled into the area by discriminatory real estate practices after

World War II, the area housed mostly northern Europeans (Scott, Newell). In the 1910s,

African Americans who had been crowded into the lower section of Northwest Portland

(centered around what is now NW Broadway) began to trickle into the area along North

Russell Street west of Williams Avenue (in present-day Eliot) and also along lower North

Broadway near today's Memorial Coliseum and Rose Quarter (immediately south of the

present-day Boise neighborhood). Most of this second area was originally platted as

McMillen's Addition, part of East Portland, and was loosely called Lower Albina. African 
Americans gradually migrated north and east, filling voids in the neighborhoods previously occupied by European transplants, some of whom moved to more affluent neighborhoods to the north and east. The move was in many ways a positive one for Portland's African Americans, as housing in these neighborhoods was affordable, the transportation system was good, and men could find jobs as railroad porters and in the railroad shops (Roos). In his article "Black in Portland: 130 years of dislocation" Randy Gragg notes that by 1941, the vast majority of Portland's African Americans live on the east side near the Broadway Bridge, with 98.6 percent of the working population employed in the railroad yards of Union Station and lower Albina.

The African American community grew rapidly in North and Northeast Portland upon America's entry into World War II, when a large influx of Black workers moved to Portland to fill jobs for the local war effort, with most of them in the large shipbuilding yards on the Columbia River. The surge also created a housing shortage, especially for African Americans, who faced discrimination. In 1942, a large federally-funded community housing development called Vanport was built in outer North Portland to house shipyard workers, many of whom were African Americans (Roos).

After the war, the shipyards closed and a good portion of Black workers left Portland because of lack of work and widespread discrimination (Roos). Many remained, however. According to local historian Thomas Robinson, as many as 5,000 African Americans (which was more than twice the entire Black population of Portland before the war), resided in Vanport when, on Memorial Day, May 30, 1948, swollen by weeks of heavy rain, the 
Columbia River breached the Northern Pacific Railway embankment and rushed through the low-lying community, completely destroying it (Abbott). Thousands of people were left homeless, and Portland's longstanding practice of residential segregation (enforced in many cases by deed restrictions which explicitly forbade Black and other minority residents from settling in some areas) complicated the question of where to provide temporary housing for Vanport's Black refugees. They were initially housed in war-surplus temporary houses on Guilds Lake (also built to provide temporary housing for workers supporting the war effort). Two weeks later, the government provided trailers to augment the temporary housing for Vaport's survivors at Guilds Lake. After three more weeks of living in these conditions, residents drove to Salem to protest the "kennels on wheels." The Guilds Lake temporary housing project was dismantled and closed without making any official effort to resettle the flood victims (Robinson). Refugees crowded into Portland- more than a thousand of the flooded families were African Americans who could find housing only in the growing ghetto in North Portland, including most of the Albina area (Abbott). 


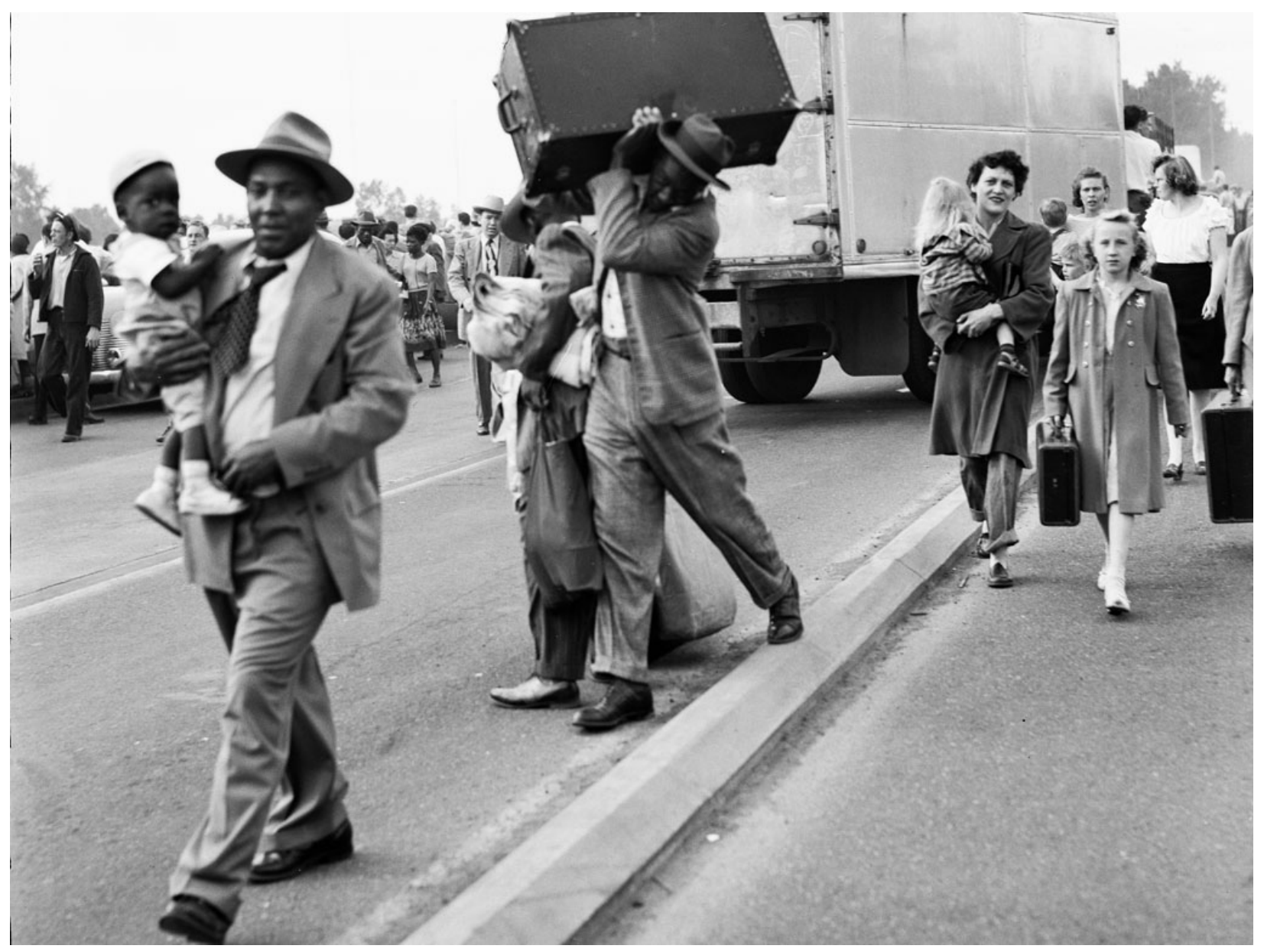

Survivors of the Vanport flood on N Denver Avenue, May 30, 1948 (Historic Photo Archive)

Karen Gibson notes that the Federal Housing Act (which, in its amended 1954 version introduces the term "urban renewal" to America) gave cities the tools they needed to achieve the national goal of clearing slums, and local officials used them by systematically deeming Black neighborhoods "blighted" and in need of revitalization. Thus, "not long after Black Portlanders got settled in Lower Albina, city leaders were making plans to convert the land, which was the heart of their community, into commercial, industrial, and institutional uses" (Gibson). 
In 1956, voters approved the construction of the Memorial Coliseum in the Eliot neighborhood, which destroyed commercial establishments and 476 homes, roughly half of them inhabited by African Americans (Gibson). The Federal Aid Highway Act of 1956 made Federal money available to cities across the nation, facilitating ever more rapid suburbanization and cutting straight through the hearts of cities already struggling against the pressures of disinvestment and deindustrialization. In Portland's case, several hundred (mostly Black-occupied) housing units were demolished in the Eliot neighborhood to make way for Interstate 5 (still known by many longtime residents as "the Minnesota Freeway" because its construction cut along the route of North Minnesota Avenue) and Highway 99, both running north/south through Albina (Gibson).

Perhaps the ultimate injustice suffered by Portland's African American community at the hands of urban renewal planners was the Emanuel Hospital expansion project, in the heart of the already fragmented Albina district. When it came time for local officials to pursue grant funds from the federal government to expand Emanuel Hospital, the 1966 grant application read, in part: "There is little doubt that the greatest concentration of Portland's urban blight can be found in the Albina area encompassing the Emanuel Hospital. This area contains the highest concentration of low-income families and experiences the highest incidence rate of crime in the City of Portland. Approximately 75 percent to 80 percent of Portland's Negro population live within the area. The area contains a high percentage of substandard housing and a high rate of unemployment." Portland won the grant, and demolition of buildings began in the late 1960s. Within a few years the federal 
money ran out for Emanuel Hospital expansion - after the demolition was complete (Loving).

Nine square blocks of mostly black-occupied residential and commercial buildings were razed to make way for expansion of the hospital complex, including 209 houses and the core business section of the Black community along Russell Street and Williams Avenue. Neighbors created an association (The Emanuel Displaced Persons Association) which vigorously opposed the condemnation of residents' homes, to no avail. For nearly forty years almost all of the cleared land sat vacant, and the Portland Development Commission (PDC), the city's urban renewal agency which oversaw the project, refused all further community proposals to use the space (Robinson).

In its Interstate Corridor Urban Renewal Plan (2000), the PDC acknowledged the sad legacy of urban renewal and public infrastructure projects in inner Northeast Portland:

“Past large scale public projects have been harmful to many, particularly members of the African-American community, entailing the involuntary displacement of residents and businesses for projects such as Memorial Coliseum, the I-5 freeway, and Emanuel Hospital. The negative legacy of urban renewal, and of these other large scale public projects in this community, still lingers."

The commission further acknowledged that the displacement of families, residents, and businesses was only one negative aspect of the area's history with regard to public projects. The construction of the I-5 freeway (and the resulting fragmentation of the community) 
contributed to large-scale disinvestment, particularly along the area's once vibrant commercial corridors (such as Mississippi, Vancouver/Williams, and Interstate).

For many residents who suffered through the devastation wrought by urban renewal and public infrastructure projects, acknowledgements of prior mistakes and injustices do little to allay concerns that public officials may not have their best interests at heart when major projects are considered. Pauline Bradford, an Albina resident quoted in the Interstate Corridor Urban Renewal Plan, summed up the legacy of urban renewal and the City's history of relations with its Black community:

“People were displaced-life investments and achievements were disrupted with no chance to rebuild. All people who were affected by condemnation had a difficult time re-establishing their lives. African Americans had an especially hard time achieving their goals - they faced discrimination, redlining, and the perception that they were considered a bad risk for the programs that were supposedly designed to assist them."

Injustices against Portland's Black community didn't end with urban renewal and public infrastructure projects. Even though the Civil Rights Act of 1964 made racial deed restrictions on housing illegal, the widespread practice of "redlining"-institutionalized discrimination carried out by lenders and real estate professionals - continued to mean that real estate agents steered African Americans and other ethnic minorities to certain areas. As late as 1990, the Oregonian exposed a form of redlining by banks and lenders who purposely denied African Americans loans to buy homes in North and Northeast Portland (the story, titled "Blueprint for a Slum" detailed the city's neglect and lenders' illegal 
practices, finding that the practice contributed to the fact that Northeast Portland held onethird of the city's abandoned homes, with 26 percent in just two neighborhoods, Boise and King). In Portland, that meant a majority of Black residents who had no options other than living in Boise or other desperately disinvested neighborhoods also had no access to financing that would allow them to own property, accumulate wealth, and hold a greater stake in their neighborhood.

According to Karen Gibson, neighborhood disinvestment, which involves the systematic withdrawal of capital (essential to a viable housing market and business community) and the neglect of public services such as schools, building, street, and park maintenance, garbage collection, and transportation, plagued Boise and the other Albina neighborhoods (Gibson). In “Bleeding Albina: A History of Community Disinvestment, 19402000," Gibson states that "when the public and private sectors make a decision to disinvest, it is essentially proclaiming an area unworthy and ensuring its decline. In this view, gentrification is not just a matter of individual preferences for older centrally located neighborhoods; it is a matter of financial and governmental decisions." Wholesale disinvestment, coupled with its long history of victimization at the hands of urban renewal and public infrastructure projects, left Boise virtually devastated by the 1980 s. 


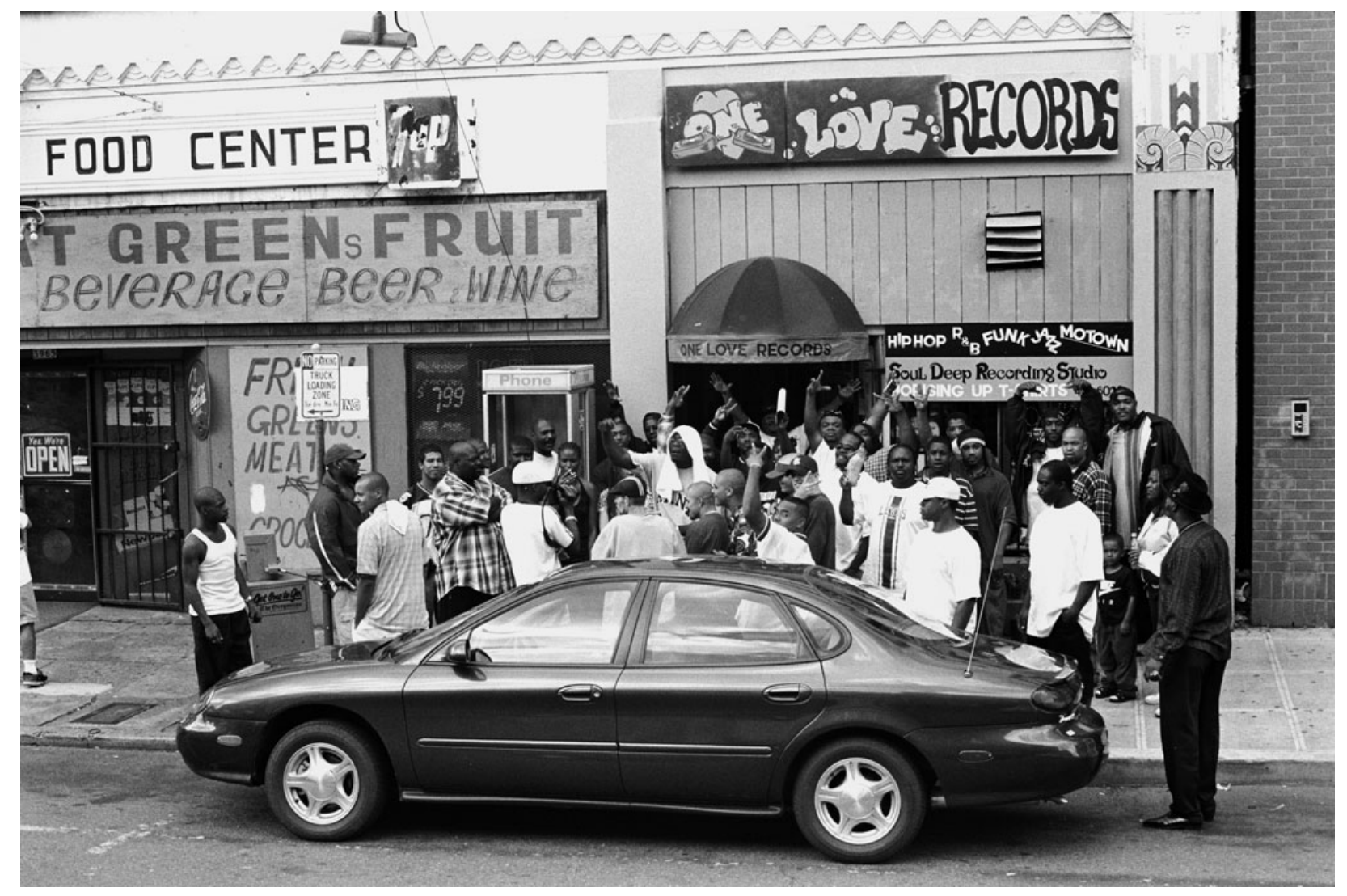

Touring rappers congregate in front of One Love Records on N Mississippi at Shaver, August 21, 1999 (Historic Photo Archive)

Vulnerability to gentrification

During the ' $80 \mathrm{~s}$, disinvestment in the Albina area continued until problems became so severe that politicians finally took notice. As Karen Gibson notes in "Bleeding Albina," “Economic stagnation, population loss, housing abandonment, crack cocaine, gang warfare, redlining, and speculation were all part of the scene." In terms of housing and neighborhood conditions, this was the period when Boise and Albina hit rock bottom. Between 1950 and 1980, Albina lost over 57\% of its housing stock, with the total number of units falling from 5072 to 2169 (Robinson). The Albina population had thinned by nearly 27 
thousand people since 1950. The value of homes dropped to 58 percent of the city's median - the decline was so dramatic that nine neighborhoods received a special reassessment of property values. Some homes sold for half of their assessed value. Absentee landlordism reached its height by 1989, when only 44 percent of homes in Albina were owner-occupied (Gibson).

All of these factors made the Albina district, and Boise in particular, especially vulnerable. Gibson describes some of the factors that made Albina an attractive target for gentrification and redevelopment, and the dramatic shift that resulted:

"The occupation of prime central city land in a region with an urban growth boundary and in a city aggressively seeking to capture population growth, coupled with an economic boom, resulted in very rapid gentrification and racial transition in the 1990s ... At the beginning of the decade, the worry was abandonment; at the end, it was the preservation of affordable housing. By 1999, Blacks owned 36 percent fewer homes, while Whites had 43 percent more than a decade earlier" (Gibson).

This assessment is supported by the Boise Neighborhood Plan, developed by the Portland Bureau of Planning in conjunction with the Albina Community Plan and adopted by the City Council in 1993, which claims that one reason the district and neighborhood plans were developed is that considerable change "is inevitable in inner north and northeast Portland with or without governmental action." Citing projections of rapid population growth for the metropolitan area, the document notes that locations for new housing and businesses close to the central city would be at a premium. 


\begin{abstract}
"Land suitable for development and redevelopment is already very scarce in Portland's inner west side and sites in northeast Portland will become increasingly attractive alternatives. Also, Northeast contains many attractive features as a living environment and place to do business. These include distinctive older housing and commercial buildings, including some of historic significance. It also has tree lined streets with curbs and sidewalks, spacious yards, established sewer and water services and excellent access to the freeway, the airport and both the Willamette and the Columbia Rivers."
\end{abstract}

The scarcity of available land and housing stock near the central city, driven by an economy rebounding from recent recession, was certainly a driving force behind the rapid gentrification of Boise. Portland's Urban Growth Boundary, designed to conserve forest and agricultural land in the city's vicinity, served to promote density and further contributed to the scarcity of urban housing. Local historian Thomas Robinson points to the gentrification of other districts in Portland, including the Northwest Alphabet district and the Hawthorne and Belmont districts in Southeast Portland as a contributing factor in the subsequent gentrification of Boise. A significant number of (mostly White) people left these areas due to rapidly increasing rents, and with North and Northeast Portland being the last affordable rent districts within close proximity to downtown and century-old homes of similar character to those found in other gentrified or gentrifying areas available at substantially lower prices, the results were not altogether unpredictable. 
Robinson also cites the property tax limitations enacted by Oregon voters in the 1990s as a factor that contributed to the vulnerability of inner North and Northeast Portland to the forces of gentrification. Measure 5, which passed in 1990 and began what became known as the "Oregon Tax Revolt," capped property tax rates at 1.5 percent, or $\$ 15$ per $\$ 1,000$ of assessed value. Of more immediate importance to the issue of gentrification in Boise and other inner North and Northeast Portland neighborhoods was Measure 47, passed in 1996, which rolled back every property's assessed values to the levels they were at in 1995 (when property values in disinvested neighborhoods like Boise were near rock bottom), decreased them by another 10 percent, and mandated that the growth of assessed values could increase no more than 3 percent per year (Measure 47 was badly written and not workable as a law, so the Oregon Legislature rewrote it, without changing its basic provisions, as Measure 50, which voters approved in 1997 [Pitkin, 2007]).

In his 2007 Willamette Week article "Spot the Differences!" James Pitkin points out that rapid gentrification in neighborhoods like Boise has dramatically increased property values, yet Oregon's tax system makes no room for changes in real-world values, and taxes in those neighborhoods are a steal because they still reflect 1995 prices. Meanwhile, he writes, property owners in other parts of the city, due to higher values at the time Measure 47 was written, pay dramatically more in taxes (even though, in many cases, their property values have not increased at anywhere near the rate of recently revitalized areas). Depending on where a property is located, it could be assessed at 25 percent of its real market value or 70 percent (meaning a potential difference of several thousand dollars per year among comparably priced homes), and that disparity will continue to grow wider as 
the years pass and real prices drift ever further from their 1995 levels. Under Measure 50, assessed values can grow only 3 percent a year and properties are not reassessed when they're sold. The only exception is for permitted improvements or new construction, but added value is calculated using a ratio that shrinks it down to Measure 50 levels rather than what the improvements are actually worth, meaning new structures are assessed as if they'd been built in 1995 (Pitkin, 2007). According to Robinson, this served to entice a horde of homebuyers and investors, ensuring that property taxes on their investments would not rise at a level commensurate with the property's value. In the late '90s, he says, "the gold rush took over."

Oregon's tax law adds a unique dimension to the phenomenon of gentrification in Portland, as the typical assumption that increasing property taxes (and corresponding rent increases) driven up by speculation and investment leads to residents being "priced out" of their homes doesn't hold here. Residents were certainly priced out, but not as a result of burdensome property taxes-in fact, just the opposite is true. The astoundingly low property tax rates in the neighborhood served to drive gentrification, and the long legacy of disinvestment and institutional racism that contributed to low rates of homeownership among Blacks made them especially vulnerable to displacement, as landlords sought to capitalize on their suddenly very desirable properties.

Investment and Revitalization

In the 1980 s a new direction in urban renewal, geared toward economic development and housing, brought Portland its first community development corporations (CDCs), long 
after CDCs had taken root in Eastern cities. The creation of CDCs in Portland-there were 27 at the peak in the mid 1990s, several of which were active in Boise -was a citizen-initiated movement. The first Portland $\mathrm{CDC}, \mathrm{REACH}$, was born out of a series of meetings organized by activists and activist organizations, including the Center for Democratic Education and members of the Community Economic Development Task Force (Johnson).

According to Steven Reed Johnson, REACH's community development work took off when it broadened its focus from individual housing restorations to neighborhood action plans. In 1989, REACH created its first neighborhood action plan for the Brooklyn neighborhood in southeast Portland, which was followed by two similar action plans in the Clinton Street area Belmont Street areas. The organization was presented with the Volunteer Action Award by President Clinton for its efforts, and its action planning process was adopted by the City of Portland's Bureau of Housing and Community Development (BHCD) as the Target Area Designation Program (TAD) (Johnson). The TAD program would play a key role in the revitalization of the Mississippi Avenue business corridor and the Boise neighborhood by providing development resources to businesses and financing and grant opportunities for local property owners.

Several CDCs and related enterprises, such as Housing Our Families, Franciscan Enterprise, Sabin CDC, Northeast CDC, and Habitat for Humanity, were all operating in Boise and the surrounding Albina neighborhoods from the early 1990s onward (Hoereth). Most were involved in the acquisition and rehabilitation of single family homes and acquisition and development of vacant lots, which were plentiful during the early years of CDC 
involvement in Boise and Albina due to abandonment, condemnation, and tax foreclosure (the nonprofit housing industry in Portland boomed in the 1990s, thanks in large part to a gift of several hundred housing units from the city of Portland to local Community Development Corporations [Gibson]). There were concerns, however, that the community development support system could not sustain several CDCs competing for limited resources in the same neighborhoods, as competition for developable land with each other and with the private sector (Hoereth). Ultimately, these concerns proved prescient. As CDCs were successful in helping to improve conditions and housing demands increased in Boise and Albina, organizations found themselves increasingly priced out of the market for the mainstay of their projects (Johnson). Several CDCs that operated in Boise in the 1990s and early 2000s ultimately ceased operations, shifted their focus away from housing development, or looked elsewhere for opportunities to develop affordable housing.

Concurrent with the work of the CDCs, the Bureau of Planning drafted the Albina Community Plan in the early 1990s, as well as individual plans for Boise and other inner North and Northeast Portland neighborhoods, which outlined the area's deficiencies and numerous strategies to address them. PDC and the Bureau of Housing and Community Development were tasked with the heavy lifting-facilitating business development, increasing property values, and improving housing conditions chief among their responsibilities. After the Albina Community Plan was adopted, PDC established the Northeast Target Area, administered by its Economic Development Program, to provide storefront improvement grants, development financing, and technical assistance to business owners. BHCD was the city bureau charged with distributing funds from HUD's 
Community Development Block Grant program. In 1999, the agency created the Mississippi Historic District Target Area along the Mississippi Avenue business corridor (it also helped to develop the Alberta Arts District on NE Alberta Street in the King neighborhood). A loan fund was established combining $\$ 8.0$ million in HUD Section 108 Loan Guarantee Program funds with a \$2.25 million Economic Development Initiative (EDI) grant to support new investment in the targeted areas. These funds enabled the City to write down the interest rate of each loan and to establish a loan loss reserve.

Subsequent to the efforts of concerned local residents, CDCs, and the small-scale target area programs came the most recent episode in urban renewal and the building of civic infrastructure in Albina. The project revolved around the construction of a north-south light rail system (the Interstate MAX line), connecting downtown to north Portland. Options for the placement of the route emerged in 1992 during the process of developing the Albina Community Plan. Albina residents, stakeholders, and city planners debated routes along Martin Luther King Blvd., Williams Avenue, I-5, and Interstate Avenue. In the end, a route along Interstate Avenue prevailed. In 1999 TriMet (the regional transportation authority) and the Portland Development Commission created the Interstate Corridor Urban Renewal Advisory Committee to oversee the development of an urban renewal plan for the Interstate Corridor, and subsequently created four working committees to create action plans related to economic development, community livability, housing, and transportation. The 90 people involved with Intestate Urban Renewal Area committees represented 69 different government agencies, private businesses, and nonprofit organizations (Johnson). Community stakeholders included on the committees insisted upon assurances that 
investments would be made in programs to prevent displacement of vulnerable residents once values began to rise and that URA money would support existing local businesses and create jobs for community members, to which PDC agreed.

Urban Renewal agencies use Tax Increment Financing (TIF) to fund development within Urban Renewal Areas (URAs). The authority then forms a district with a limited lifespan, typically 20 years, and issues debt to finance capital projects in the district that will encourage redevelopment and leverage private investment. Using TIF requires a local government, typically under the authority of its redevelopment authority (in this case PDC), to define an area where redevelopment is desired as "decaying" or "blighted." While Boise (and much of the rest of the Interstate URA) undeniably met the criteria for being deemed "blighted," the designation carries with it vestiges of the previous era of urban renewal, wherein Black and other underrepresented populations were subject to all manner of misdealing. In Portland, 17 major redevelopment projects have been funded through urban renewal dollars and TIF since 1958 (Stapleton). Capital projects within a TIF district are constructed with debt that is paid off by the increased property taxes of the district after the district is formed (Stapleton). Taxes are still collected by the taxing jurisdiction at a base rate determined at the time the district is established, but the "increment," or increase in tax revenue (ostensibly) resulting from investment in the district is used to pay debt obligations on the bonds issued for the project. In other words, counties and municipalities accept the proposition that accepting twenty years or more of tax revenue frozen at rates yielded by "blighted" areas is worth the payoff (presumably an economically vital area producing significantly greater tax revenue when the TIF district expires). 
The PDC seems satisfied with the results of its recent urban renewal projects. In a December 2012 report on economic indicators within its Urban Renewal Areas, the commission found that "compared to other areas of the city and to the city as a whole, employment, average wages and real estate values in the URAs have grown during our study period (1996 through 2010) ... Real estate values in the URAs also increased almost twice as much as in other parts of the city." The report also notes that in the URAs studied, the number of private sector jobs and average wages each made significant gains.

The Interstate Corridor URA, particularly in long-disinvested areas like Boise, was a pretty safe bet to yield positive economic returns, says Richard Stapleton. In his study "Tax Increment Financing: Comparing Approaches in Northwest States," he claims that Measures 5 and 50 changed the rules of the game for TIF in Oregon and have forced cities to very carefully assess the revenue generation potential of a district before moving past the feasibility stage of plan development. He states that "larger urban renewal areas such as the Interstate Corridor Urban Renewal Plan Area carry much less inherent risk than districts that are significantly underdeveloped, such as the South Waterfront Urban Renewal Area." This is due to the fact that the Interstate URA encompasses a large patchwork of already developed land in an area that has seen substantial real market property value appreciation since the approval of Measure 50. Stapleton writes, "Because Measure 50 has suppressed assessed valuation in the Interstate corridor well below real market values for the last 12 years, there is a minimum appreciation of approximately $3 \%$ per year that can be assumed in the district before factoring in new construction." 


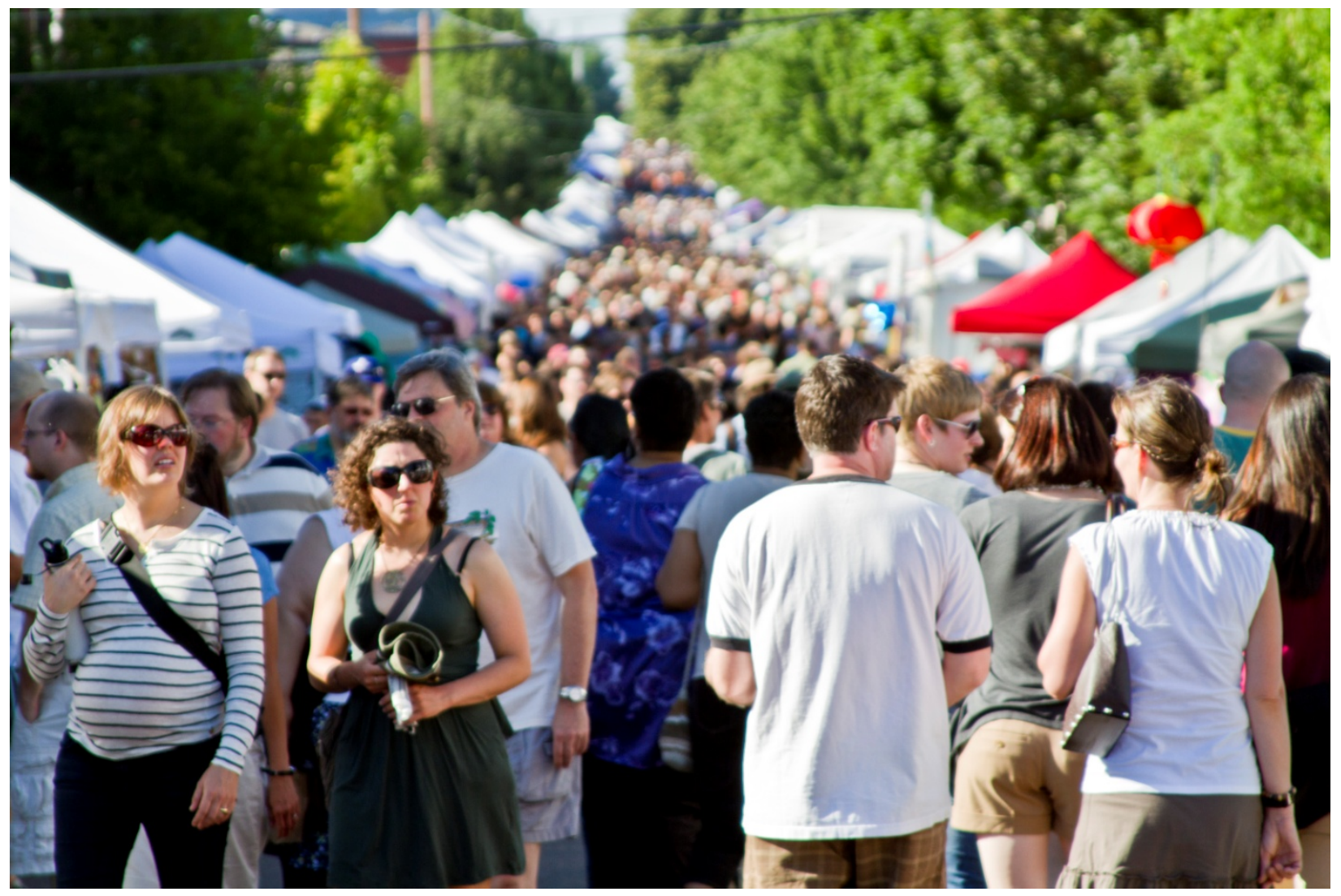

Mississippi Street Fair

Kay Newell is a longtime Boise resident, activist, and business owner on Mississippi Avenue, who is credited by many as instrumental in the Boise neighborhood's transition from a drug- and crime-ridden slum to one of the trendiest business districts and most desirable neighborhoods in the city. She and other local residents and business owners, with the help of BHCD Target Area resources, organized the annual Mississippi Street Fair, which was intended to cast the neighborhood in a positive light (it was regularly the subject of negative press for its reputation as a haven for the worst the city had to offer) and raise funds for the nearby Albina Youth Opportunity School and Boise-Eliot Elementary. The fair became an overwhelming success, drawing thousands of people each year from all over the 
city to take in local crafts, food, and music. The positive recognition of the neighborhood that the fair generated proved to be a stepping stone.

She says that the she doesn't believe the Urban Renewal Area was a decisive factor in the revitalization of Mississippi Avenue and the Boise neighborhood, but it has certainly counted the economic growth in Boise among its successes (and collected the increased tax revenue to pay down TIF obligations). She has served on the Interstate Corridor Urban Renewal Area Advisory Committee since its inception, and says that while large-scale development along the Mississippi Avenue business corridor increased substantially after the formation of the URA, she believes that the groundwork for that investment was laid prior to the URA designation. She says that PDC has invested very little through the URA along Mississippi, and that most investment that's taken place since the URA was enacted has been driven by private speculation. Sara King of PDC, a neighborhood manager who works on the Interstate URA, confirmed that little PDC money has been invested directly on Mississippi through the URA. She did say that PDC has been active in providing technical assistance and limited financing for development elsewhere in Boise, particularly along the Vancouver/Williams commercial corridor, another conspicuously gentrifying part of the neighborhood (which is itself designated as a PDC target area).

Ms. Newell describes the state of the Boise neighborhood in the early 1990s, when she first moved there and opened her store, as extremely bleak. Gang activity, violence, widespread theft and vandalism, prostitution, and especially drugs, plagued the neighborhood. She says that the corner of Mississippi and Shaver Street was an open-air 
drug market, with traffic streaming by day and night. Businesses struggled to stay open because the neighborhood was so economically depressed that residents couldn't support them. She points to the early 1990s, when the city made efforts to step up enforcement of building codes, which forced some delinquent property owners to improve their properties, sell, or be condemned. Most important, she said, were the mid-to-late '90s and the two target area programs, both of which offered business owners storefront improvement grants, development loans, and technical assistance (including a dedicated staffer from $\mathrm{BHCD}$ ), as decisive in terms of building a coalition of local residents and business owners who bought into cooperation with public agencies and were committed to making their own investments in the community. This view is seemingly supported by a 2002 report commissioned by the Mississippi Historic District Target Area to evaluate the project's progress:

"In the last several years there have been a number of development and redevelopment projects and business locations on Mississippi Avenue. Development of the Pistils Plant Nursery building and site, renovation of storefronts and single family homes for location of the Purple Parlor, Mississippi Pizza, Fresh Pot, and Grandfather's reopening, and opening of the Rebuilding Center. Storefront improvement projects have occurred at a number of existing business locations.

The development and redevelopment of commercial sites by business owners for their own use often precedes larger development in areas where rents are too low to 
support speculative development. Speculative development occurs when profit can be generated by rents (or sales prices) in excess of development costs.

The cumulative effect of the smaller development/redevelopment projects and business openings on Mississippi has been a more active street front, enhanced district character, and stronger draw for customers from both the primary market area and surrounding neighborhoods. This type of activity can act as a catalyst making larger development/ redevelopment projects more viable and attractive to property owners and potential investors." (E.D. Hovee \& Company for Mississippi Historic District Target Area: Mississippi Historic District Target Area Economic Development Strategy)

The reinvestment, along with the booming economy and the cheap housing stock, unleashed a flood of buyers over the area. One private investor who had a tremendous impact on the transition of the Mississippi business corridor is Brian Wannamaker. In a March 2013 Willamette Week article, Aaron Mesh describes Wannamaker's influence, saying he is "best known as the man who gentrified North Mississippi Avenue, turning the street from a crack-blighted byway into a chic boutique strip a decade ago. He and his companies own 12 buildings with 150 residents and 10 businesses. In all, these holdings have a net worth of \$12 million."

Wannamaker started renovating houses in the Lloyd District shortly after moving to Portland in the mid-80s. He later shifted his attention to commercial properties-especially on Mississippi Avenue. Mesh reports that "he picked six apartment buildings, most near the 
intersection of North Mississippi and Shaver Street, and chose the retail anchors: the candlelit Crow Bar, the auteur-stocked DVD rental store Video Verite, the upscale soul-food purveyor Miss Delta."

"I felt like I could buy...the whole street is an exaggeration," Wannamaker says (quoted in the WW story). "But a lot of the street."

After years of disinvestment and denial of capital to residents of Boise, the neighborhood was ripe for investors like Wannamaker, who in many cases were able to pay cash for properties whose values were severely depressed. Values didn't stay that way for long. During the '90s, prices more than quadrupled in some neighborhoods of Albina (Scott). "The market burned so hot that homeowners received knocks on their door from buyers offering cash-or in the case of seniors like former State Senator Avel Gordly's father, an offer at his hospital bed," Aaron Scott reports in "By the Grace of God." "Presented with cash figures many times what they paid in the '40s and '50s, owners, especially seniors or their surviving children, often sold, only to learn later they were severely underpaid and couldn't afford to re-buy in the neighborhood."

While it's true that a significant number of African Americans sold their homes and left the neighborhood by choice (with some reaping the material rewards of revitalization), the greatest driver of the Black exodus from Boise was displacement of Black renters, expelled by skyrocketing prices and dwindling rental stock as new owners moved in (Scott). Scott reports that the number of residents receiving rental assistance in the two zip codes constituting most of Albina dropped 58 percent in the first decade of the 2000 s (citing 
information from Home Forward, Portland's housing authority). This is another indication that many Black residents had little choice when it came to relocation- more than 8,800 Black Multnomah County residents (nearly 1 in 5) rely on some sort of assistance from the housing authority (Schmidt), and the evidence suggests that housing opportunities for such residents in and around Boise have dwindled significantly. In some cases, entire affordablehousing complexes were evicted so owners could make a few improvements and raise rents by hundreds or turn them into condos (Scott). Conversion of apartments and other multifamily housing (particularly low-rent housing) into condos or higher-rent developments is a hallmark of development in gentrifying areas.

Broken Promises

To provide the required local match of federal funding for construction of the proposed Interstate light rail project, the city formed the Interstate Corridor Urban Renewal Area in 2000. Knowing demolition and displacement from previous urban renewal projects still hung over the area, PDC enlisted 54 community members to help draft the project's plan. The adopted policies explicitly stated that any increased tax revenues from rising property values should primarily benefit existing residents and protect against gentrification and displacement (Scott). Then in 2002, a recession hit and tax activists won a court case limiting how PDC would be allowed to generate revenue. The agency suspended the plan's 18 anti-displacement projects and small-business-assistance programs, proceeding only with reconstruction of the housing development Columbia Villa (now called New Columbia) and the one project that promised to speed displacement, the Interstate MAX (Scott). 
In a 2011 story for the Oregonian titled "Lessons learned? What Portland leaders did and didn't do - as people of color were forced to the fringes," Nikole Hannah-Jones points out that PDC failed to follow through on the promised anti-displacement and community investment measures, and instead the Portland City Council created an anti-displacement pilot project that spread $\$ 1.5$ million to nonprofits. Developments such as this opened old wounds for some Portland residents.

"The Portland Development Commission's plan to move forward with construction of the Interstate light rail while freezing other projects in the Interstate Urban Renewal Area has residents worried that history will repeat itself. The residents are concerned about housing displacement, which is caused by real estate prices rapidly outpacing incomes. The city is currently investing millions of urban renewal dollars in light rail, which is fueling the real estate market, with no program in place to protect residents from displacement. Despite the Portland Development Commission's attempts to improve its image, this plan reminds many residents of the negative legacy of past large scale public projects in the Interstate Corridor, such as the Memorial Coliseum, the I-5 Freeway, and Emmanuel hospital, which displaced hundreds of residents and businesses" (Hop Hopkins, personal communication with Steven Reed Johnson, October 26, 2001).

Those concerns proved to be warranted. "It left the rest of the district naked," said Sam Adams, then Mayor Vera Katz's chief of staff (quoted in Aaron Scott's February 2012 Willamette Week article "By the Grace of God"). "If you put in light rail, without having 
enough control of property and programs in place and funded, gentrification will occur. And it did." Inner North and Northeast Portland's 22 census tracts lost 8,536 Black residents between 2000 and 2010, while 32 tracts east of 82nd Avenue gained 9,134 (Gragg). "We anticipated gentrification and welcomed it to a degree," Carl Talton, cofounder of the North/Northeast Economic Development Alliance and former PDC chair, says in Gragg's Portland Monthly article. "What we didn't anticipate was that we wouldn't be able to manage it and that it would just run away."

With or without PDC's broken promises of anti-displacement and community development measures within the Interstate URA, there's reason to be skeptical of claims that TIF-financed urban renewal programs offer any hope for actual community capacity building. That's because TIF money can only be allocated to physical development projects that is, projects that are likely to yield at least enough additional tax revenue to pay off debt obligations within the specified period. PDC's claims of commitment to equity and development meant to benefit all residents of its URAs ring hollow in this context. As one astute observer of urban renewal put it, "Buildings don't develop. People do."

Where to go from here?

"In America's cities, racial and ethnic enclaves come and go," says Aaron Scott in his Willamette Week piece, which details the gentrification-based displacement of African Americans from their inner Northeast Portland Neighborhoods and its effect on their churches and community ties. "In one sense, then, the movement of Blacks from North and Northeast Portland to the city's fringes is merely the latest chapter in a 130-year history of 
forced dislocations of the African American community." He says that "Portland's history of poor dealings with its African American population has deep roots and seemingly perennial blooms," citing Oregon's status as the first state to enter the union with an exclusion law barring African Americans from residing, working, and voting in the state (in 1859), Portland's earliest urban renewal projects, which devastated the residential and commercial heart of the Black community, and the fact that the practice of redlining continued in Portland until at least 1990.

Yet, as Scott points out, with no other established Black neighborhood to move to, the ramifications for Black residents at risk of displacement from their neighborhood are greater, especially when it coincides with a troubling development: Portland's African Americans now rank at or near the bottom of almost every socioeconomic measure, below Native Americans, Hispanics, Asians, and Caucasians. Scott reports that Black Portlanders are actually worse off today by many counts than before the civil rights movement. "Homeownership has dropped, the rate of college education has barely budged, especially in comparison to its growth among whites, and per capita income has basically stagnated since 1979" while it has increased for whites by roughly one-third since then (Scott).

Yet, as Scott, Karen Gibson and others have noted, those concerns go largely unmentioned in the many national magazines and urban planning seminars hailing Portland as one the nation's most desirable and progressive places to live. Scott points out that the "new" Albina's lively mix of indie culture and aspiring middle class is in many regards central to the city's image. He notes that three decades of liberal leadership under mayors Bud 
Clark, Vera Katz, Tom Potter, and Sam Adams has even led to claims that Portland is "postracial." But, he says, "That laurel of livability at best ignores and at worst comes at the expense of a black community struggling to hang together against decades of neglect, discrimination, and racism - institutional and interpersonal, overt and tacit."

Former mayor Adams echoed those sentiments in a quote included in Scott's article: "We're not postracial when comparisons between White Portland and African-American Portland are so disparate, especially when you measure it against our self-proclaimed values as an equitable and livable city. That is not postracial - that is denial."

Postracial or not, White home seekers, (many of whom were) for decades unwilling to move into Black neighborhoods (but in many cases quick to leave neighborhoods into which Blacks moved), have contributed to exploding demand for property in what had been an overwhelmingly African American neighborhood (McGee). As Whites have found bargains in Boise and other inner Northeast Portland neighborhoods, many Blacks have moved to Portland's outer suburbs in order to find affordable housing, far from their traditional neighborhoods. While some African Americans displaced from inner North and Northeast Portland have scattered to Vancouver, Beaverton, St. Johns, and Hillsboro, most who have moved went east of 82 nd Avenue, to the region colloquially known as "The Numbers." The black population in East Portland alone grew 151 percent between 1990 and 2010, and the number of subsidized renters more than doubled in some parts of East Portland, where rents are considerably lower than closer in (Scott). 
"Places where we could never live-Gresham, East Portland-where no one would rent to us, now we call that 'the new ghetto,'” Roberta Tyler says in Scott's article. Despite this mass migration eastward, very little of the African American community's infrastructure followed it. Businesses that still cater specifically to Blacks largely remain in Albina (if they've survived the demographic transition), meaning people must commute back to get their hair done, to visit restaurants that serve the food they grew up with, even to find nylons that match their skin tone. Culturally specific social and medical services haven't followed, either. The commutes often come at a great cost for isolated, low-income people, if they can make them at all (Scott).

Relocation to new schools has also proven to be a challenge for many African American students and their families. Black students find themselves a small minority in East Portland schools, where teachers and administrators can lack cultural competency skills, and where Black history and Black role models often are not a feature of the curriculum. The ramifications are real, Scott says: in 2010, only 47.5 percent of African American students graduated high school in Multnomah County-the number was as low as 38.5 percent for the Gresham Barlow District-and black students were more than twice as likely to be expelled or drop out as their white peers (Scott).

\section{Conclusion}

The difficult transition facing many African American Portlanders seems to be just the latest in a long line of hardships brought to bear on a particularly vulnerable population. The exodus of much of the Black community from Boise and other inner Northeast 
neighborhoods must be understood to be a real and pressing concern if equity is a true aim in Portland. And while the movement of African Americans away from their homes and neighborhoods may not be as directly attributable to a single cause as it was when their homes and businesses were bulldozed, neither is it simply a coincidence that they've found themselves on the wrong end of another civic "improvement" effort. Although the circumstances surrounding the current phenomenon are more complex than previous cases of injustice and misfortune for Portland's Black community, there are a number of lessons to be learned.

First, the long, sad legacy of public misdealing and disinvestment in Boise and other Black neighborhoods had a tremendous negative impact, which contributed significantly to the vulnerability of these neighborhoods to such swift transformation. Without access to mortgage capital, low rates of Black homeownership left Boise and the rest of Albina unable to resist the forces of gentrification and displacement, and longstanding public neglect of these neighborhoods suppressed value, making many properties easy pickings for speculators.

Next, entrenched public policies like the Urban Growth Boundary and Oregon's citizen-enacted property tax-limitation measures helped to drive speculation in Boise and inner northeast, once the rebounding local economy and the pressures of population growth and rising rents and property values elsewhere put these neighborhoods on the radar of homeseekers and investors. Long-depressed values and artificially suppressed tax 
rates made Boise's old, quality housing stock and walkable, centrally-located setting a prime candidate for gentrification.

Lastly, the influence of urban renewal and other public investment strategies, as in the past, has largely failed to benefit the Black community in Portland. While the transformation of the Mississippi Avenue business corridor is something to be lauded from an economic perspective, promises from the city's development agency to invest in the capacity of existing community members (as they did for the community's buildings and infrastructure) were not kept. The reality though, is that, promises or no, the system is broken. The preferred financing instrument used to develop Urban Renewal Areas, TIF, doesn't allow for investments in anything other than physical development, meaning that until an alternative model is adopted, claims that urban renewal will deliver lasting benefits to socially and economically vulnerable people in Portland should always be viewed skeptically. 